\title{
Regulation of Nitrogen Assimilation by the Obligate Chemolithotroph Thiobacillus neapolitanus
}

\author{
By R. F. BEUDEKER, R. RIEGMAN AND J. G. KUENEN*† \\ Department of Microbiology, University of Groningen, Kerklaan 30, 9751 NN Haren, \\ The Netherlands
}

(Received 14 May 1981; revised 19 June 1981)

\begin{abstract}
The obligate chemolithotroph Thiobacillus neapolitanus can grow with $\mathrm{NH}_{4}^{+}, \mathrm{NO}_{3}^{-}$or urea as source of nitrogen. Gradual and rapid mechanisms were detected for regulating both the activity and the rate of synthesis of enzymes required for the metabolism of these nitrogen compounds. Glutamine synthetase (GS) in combination with glutamate synthase (GOGAT) was active under most growth conditions. Alanine dehydrogenase appears to be the major pathway of $\mathrm{NH}_{4}^{+}$assimilation during energy-limited growth in the presence of excess $\mathrm{NH}_{4}^{+}$. GS was regulated in this organism by repression/derepression of enzyme synthesis, by inhibition by low molecular weight compounds, and also by adenylylation and deadenylylation. GS was deadenylylated during $\mathrm{CO}_{2^{-}}$and $\mathrm{N}$-limited growth and also during energylimited growth when $\mathrm{NO}_{3}^{-}$or urea were supplied as the nitrogen source. GS was adenylylated during energy-limited growth in the presence of $7.7 \mathrm{mM}^{-N_{4}}$. The activity of GS increased with decreasing dilution rate during $\mathrm{NH}_{4}^{+}$-limited growth, whereas the activity of GOGAT remained almost constant. The ability of whole cells to reduce $\mathrm{NO}_{3}^{-}$was derepressed during $\mathrm{N}$-limited growth. During $\mathrm{NH}_{4}^{+}$-limited growth $24 \%$ of total carbon fixed was excreted as 2-oxoglutarate, pyruvate, succinate, $p$-hydroxyphenylacetate and ethylmalonate.
\end{abstract}

\section{INTRODUCTION}

Studies on Gram-negative bacteria, and in particular on the Enterobacteriaceae, have provided a detailed knowledge of nitrogen assimilation in these organisms. In general, glutamine and glutamate serve as the nitrogen donors for biosynthetic reactions in bacteria (for review see Tyler, 1978). If available in excess, ammonia is usually assimilated by the reductive amination of 2-oxoglutarate, catalysed by glutamate dehydrogenase (GDH) to give glutamate. Glutamate may then donate its amino group to a keto acid by transamination. In contrast, when the intracellular concentration of ammonia is relatively low, ammonia is usually assimilated by glutamine synthetase (GS), which, in an ATP-dependent reaction, adds an amino group to glutamate to give glutamine. A second enzyme, glutamate synthase (GOGAT), regenerates glutamate by a reaction involving glutamine and 2-oxoglutarate, whereby two molecules of glutamate are formed at the expense of NADPH. The GDH has a lower affinity for ammonia than the GS/GOGAT system. More energy is required to assimilate ammonia via the GS/GOGAT pathway than through GDH, so in many organisms GS is fully repressed and GDH is induced when excess ammonia is available. In cells grown in a medium containing a growth-limiting nitrogen source, synthesis of GS is derepressed and the enzyme is in its biosynthetically active form. Excess ammonia not only results in repression of GS but also in a direct feedback inhibition of the enzyme. Furthermore, the

† Present address: Laboratory of Microbiology, Delft University of Technology, Julianalaan 67A, 2628 BC Delft, The Netherlands. 
activity of GS can be decreased directly by a reversible adenylylation of the enzyme. Thus the biosynthetic activity of GS can be controlled in at least three ways. It is possible to measure the fully adenylylated, biosynthetically inactive enzyme in cell-free extracts by measuring its $\mathrm{Mn}^{2+}$-dependent glutamyltransferase activity.

The complex regulation of ammonia assimilation occurs not only in Enterobacteriaceae (Tyler, 1978), but also in Pseudomonas aeruginosa (Janssen et al., 1980), in $\mathrm{N}_{2}$-fixing non-cyanobacteria (Kleinschmidt \& Kleiner, 1978; Ludwig, 1978) and in photosynthetic non-cyanobacteria (Johansson \& Gest, 1977). In $\mathrm{N}_{2}$-fixing cyanobacteria the activity of GS seems to be regulated by conversion of an active form of the enzyme to an inactive form in response to variations of concentrations of divalent cations and reducing agents. This modulation of GS, which does not involve adenylylation, can be induced by darkness or by the addition of a high concentration of ammonia (Rowell et al., 1979). GS of $\mathrm{N}_{2}$-fixing cyanobacteria is also regulated by feedback inhibition (Stacey et al., 1979).

Very little is known about the regulation of nitrogen assimilation in chemolithotrophic bacteria. Some Thiobacillus species which are unable to use exogenously supplied organic compounds as a source of energy are characterized by a lack of enzyme induction after addition of organic compounds to the growth medium. For this reason, various authors believe these organisms to be metabolically rigid (for reviews see Smith \& Hoare, 1977; Matin, 1978). This raised the question as to how rigid these organisms would be with respect to changing inorganic environmental parameters like fluctuating concentrations and sources of nitrogen. This paper describes the regulation of nitrogen assimilation in the obligate chemolithotroph Thiobacillus neapolitanus during various growth conditions in the chemostat.

\section{METHODS}

Organism and growth conditions. Thiobacillus neapolitanus strain $\mathrm{X}$ was grown in the chemostat as described by Kuenen \& Veldkamp (1973). The composition of the basal medium used in continuous cultivation for thiosulphate-limited growth of $T$. neapolitanus was the same as described previously (Beudeker et al., 1980). This medium contained $(\%, w / v): \mathrm{NH}_{4} \mathrm{Cl}, 0.04 ; \mathrm{MgSO}_{4} .7 \mathrm{H}_{2} \mathrm{O}, 0.08 ; \mathrm{K}_{2} \mathrm{HPO}_{4}, 0.05 ; \mathrm{KH}_{2} \mathrm{PO}_{4}, 0.05 ; \mathrm{Na}_{2} \mathrm{~S}_{2} \mathrm{O}_{3} .5 \mathrm{H}_{2} \mathrm{O}$, 1.0 ; in deionized water plus $2 \mathrm{ml}^{-1}$ of a trace element solution (Vishniac \& Santer, 1957). During thiosulphate-limited growth of $T$. neapolitanus, $\mathrm{NH}_{4} \mathrm{Cl}$ was replaced, where indicated, by an amount of $\mathrm{KNO}_{3}$ or urea giving the same nitrogen concentration. $\mathrm{N}$-limited growth of $T$. neapolitanus was achieved by lowering the nitrogen content of the growth medium tenfold, for example to $0.004 \%(\mathrm{w} / \mathrm{v})$ for $\mathrm{NH}_{4}^{+}$-limited growth. Excess $\mathrm{NH}_{4}^{+}$was available for thiosulphate-limited cultures, because $\mathrm{NH}_{4}^{+}$was detectable in the supernatant and addition of more $\mathrm{NH}_{4}^{+}$did not result in the formation of more cells.

During all the above growth conditions, $1 \mathrm{M}-\mathrm{Na}_{2} \mathrm{CO}_{3}$ was used for neutralization of the sulphuric acid produced from the oxidation of thiosulphate. $\mathrm{CO}_{2}$-limited growth of $T$. neapolitanus was obtained by removing $\mathrm{CO}_{2}$ from the air by sodiumasbestos (Merck): a $50 \mathrm{mM}-\mathrm{Na}_{2} \mathrm{CO}_{3}$ solution was fed into the chemostat as growth-limiting substrate. $\mathrm{NaOH}(1.0 \mathrm{M})$ was used for titration during this growth condition. Details for $\mathrm{CO}_{2}$-limited growth have been described by Kuenen \& Veldkamp (1973). The $\mathrm{N}_{2}$-fixing aerobic bacteria Azotobacter vinelandii strain $\mathrm{O}$, Beijerinckia indica NCIB 8597 and Xanthobacter flavum 301 were kindly provided by Professor J. R. Postgate. These organisms were maintained as described by Strandburg \& Wilson (1968) Ifor X. flavum as described by Biggins \& Postgate (1969)|. Bacteria were harvested from steady-state chemostat cultures (unless described otherwise), and after washing the cells in the appropriate buffer, cell-free extracts were made according to Kuenen \& Veldkamp (1973). Dithiothreitol (1 mM) was added to buffers.

Enzyme assays. Cell-free extracts were used to determine enzyme activities. Glutamine synthetase (GS; L-glutamate:ammonia ligase; EC 6.3.1.2) was assayed in three ways. (1) The biosynthetic activity (the ATP-dependent production of glutamine from glutamate and $\mathrm{NH}_{4}^{+}$) was measured at $37^{\circ} \mathrm{C}$ by following the release of inorganic phosphate from ATP as described by Shapiro \& Stadtman (1970). In Enterobacteriaceae, only deadenylylated GS catalyses glutamine synthesis. (2) The $\mathrm{Mn}^{2+}$, ADP- and arsenate-dependent production of $\gamma$-glutamyl hydroxamate from glutamine and hydroxylamine ( $\gamma$-glutamyltransferase activity) was taken as a measure of the total (adenylylated plus deadenylylated) GS activity. The procedure of Shapiro \& Stadtman (1970) was followed. (3) The effect of $\mathrm{Mg}^{2+}$ on the $\gamma$-glutamyltransferase activity was determined. Addition of high concentrations of $\mathrm{Mg}^{2+}$ to cell-free extracts always resulted in lower GS transferase activity in cell free extracts of T. neapolitanus. In Enterobacteriaceae addition of high concentrations of $\mathrm{MgCl}_{2}$ resulted in an increase of the 
deadenylylated and a decrease of the adenylylated GS, respectively (Shapiro \& Stadtman, 1970). The pH optimum for all three assays of GS was 7.3 .

For snake venom phosphodiesterase (SVD) treatment of cell-free extracts. a dialysed cell-free extract (100 $\mu$ l, containing $50 \mu \mathrm{g}$ protein) was added to $1 \mathrm{ml} 0.1 \mathrm{M}-\mathrm{Tr}$ ris/ $\mathrm{HCl}, \mathrm{pH} 8.8$. containing $1 \mathrm{mM}-\mathrm{MgCl}_{2}$. To this mixture 10 $\mu \mathrm{l} \mathrm{SVD}$ (Boehringer) was added at $37^{\circ} \mathrm{C}$. At intervals of $30 \mathrm{~min}, 100 \mu \mathrm{l}$ was assayed for GS biosynthetic activity (Ludwig, 1978).

Glutamate dehydrogenase (L-glutamate: $\mathrm{NAD}^{+}$oxidoreductase: $\mathrm{EC}$ 1.4.1.3) was assayed according to Schmidt (1974). Alanine dehydrogenase (L-alanine: $\mathrm{NAD}^{+}$oxidoreductase; $\mathrm{EC} 1.4 .1 .1$ ) activity was determined at $37^{\circ} \mathrm{C}$ following the procedure of Rowell \& Stewart (1976). Glutamate synthase (GOGAT; Lglutamate: $\mathrm{NADP}^{+}$oxidoreductase; $\mathrm{EC}$ 1.4.1.13) activity was found to be optimal following a modification of the method of Lea \& Miffin (1975). The assay mixture contained $50 \mathrm{~mm}$-Tricine buffer, $5 \mathrm{~mm}$-EDTA and 12.5 mM-mercaptoethanol adjusted to $\mathrm{pH} 7 \cdot 8: 0.5 \mathrm{mM}$-2-oxoglutarate: $0.075 \mathrm{~mm}-\mathrm{NADPH}$; and cell-free extract $(0.2$ $\mathrm{mg}$ protein per $\mathrm{ml}$ of assay mixture). Glutamine (final concentration $5 \mathrm{mM}$ ) was added to start the reaction which was followed spectrophotometrically at $340 \mathrm{~nm}$ at $28^{\circ} \mathrm{C}$. Alanine aminotransferase (L-alanine : 2-oxoglutarate aminotransferase; EC 2.6.1.2) activity was followed spectrophotometrically at $340 \mathrm{~nm}$ by coupling the production of pyruvate to NADH oxidation with lactate dehydrogenase according to Herbert et al. (1978).

$\mathrm{NO}_{3}^{-}$-reducing capacity of whole cells. An in vivo assay was used since no nitrate reductase activity was detected in vitro. Cells $(0.1 \mathrm{mg}$ protein) were washed once after centrifugation in a bench centrifuge in $0.1 \mathrm{M}$-phosphate buffer, $\mathrm{pH} 6 \cdot 8$. Propanol $\left(5 \%, \mathrm{v} / \mathrm{v}\right.$ ) and $\mathrm{NO}_{3}^{-}$(final concentration $10 \mathrm{~mm}$ ) were added to a total volume of $1 \mathrm{ml}$. $\mathrm{NO}_{2}^{-}$production was determined by adding $1 \mathrm{ml} 1 \%(\mathrm{w} / \mathrm{v})$ sulphanilamide in $\left.1 \mathrm{M}-\mathrm{HC}\right)$ and $1 \mathrm{ml} 0.01 \%(\mathrm{w} / \mathrm{v})$ naphthylethylenediamine dihydrochloride after incubation at $28{ }^{\circ} \mathrm{C}$ for various times. After centrifugation for 15 min at room temperature in a bench centrifuge, the absorbance of the supernatant at $540 \mathrm{~nm}$ was read (Jaworski, 1971).

Characterization and quantification of the excreted products. Samples of steady-state culture fluids were filtered through a G5 glass filter, brought to $\mathrm{pH} 13$ with $\mathrm{Na}_{2} \mathrm{CO}_{3}$. and freeze dried. Trimethylsilyl derivatives of the lyophilized residues were prepared according to Duran (1974). The derivatives were identified and assayed by gas-liquid chromatography according to Duran (1974).

\section{RESULTS}

Thiobacillus neapolitanus was able to use $\mathrm{NH}_{4}^{+}, \mathrm{NO}_{3}^{--}$and urea as nitrogen sources for growth. The yields of $T$. neapolitanus on $\mathrm{NH}_{4}^{+}, \mathrm{NO}_{3}^{-}$and urea during thiosulphate limitation in the chemostat were, respectively, 160,117 and $132 \mathrm{mg}$ dry wt $1^{-1}$. We were unable to grow T. neapolitanus on $\mathrm{N}_{2}$ as nitrogen source, even at very low dissolved oxygen tensions ( $5 \%$ of air saturation). Although methylamine is a $C_{1}$ compound which can be used for growth by various methylotrophs (Meiberg, 1979), it was not used as a nitrogen source by $T$. neapolitanus.

\section{Regulation of glutamine synthetase $(G S)$}

Regulation of activity by small molecules. The biosynthetic activity decreased rapidly within 5 min of the addition of a high concentration of $\mathrm{NH}_{4}^{+}$to an $\mathrm{NH}_{4}^{+}$-limited culture of $T$. neapolitanus (final concentration $7.7 \mathrm{~mm}-\mathrm{NH}_{4}^{+}$): this activity could be restored by dialysis (Table 1). Thus low molecular weight compounds had inhibited the GS biosynthetic activity. Dialysis of the extract of $\mathrm{NH}_{4}^{+}$-limited bacteria harvested before the addition of excess $\mathrm{NH}_{4}^{+}$ had no effect on the GS activity but dialysis of extract made after 5 min incubation with excess $\mathrm{NH}_{4}^{+}$fully restored the original activity. With increasing time the activity recovered by dialysis decreased, and became undetectable in the new steady state.

Regulation of glutamine synthetase activity by adenylylation. Dialysis restored only 10 to $20 \%$ of the original GS biosynthetic activity of extracts of bacteria harvested $1 \mathrm{~h}$ after the addition of excess $\mathrm{NH}_{4}^{+}$to a $\mathrm{NH}_{4}^{+}$-limited culture $\left(\mathrm{NH}_{4}^{+}\right.$shock) (Table 1). The GS transferase activity, however, had not decreased at that time, indicating that no enzyme proteolysis had occurred. Incubation of dialysed cell-free extracts with snake venom diesterase (SVD) resulted in complete restoration of the GS biosynthetic activity (Table 1). SVD is known to remove AMP residues from enzymes and thus it was concluded that GS activity in $T$. neapolitanus was also controlled by adenylylation/deadenylylation. No change was detected 
Table 1. Effect of $\mathrm{NH}_{4}^{+}$shock to a $\mathrm{NH}_{4}^{+}$-limited culture of T. neapolitanus on $\mathrm{GS}$ biosynthetic and GS transferase activities and alanine dehydrogenase activity

The dilution rate of the culture was $0.07 \mathrm{~h}^{-1}$ and the dissolved oxygen tension was $50 \%$ of air saturation. $\mathrm{NH}_{4}^{+}$was added to the culture (change-over) to give a final concentration of $7.7 \mathrm{~mm}$. Extracts were assayed after dialysis and after snake venom diesterase (SVD) treatment where indicated.

$\begin{array}{cccccc}\text { Time after } \\ \begin{array}{c}\text { change-over } \\ \text { (min) }\end{array} & \text { GS biosynthetic } & \begin{array}{c}\text { GS biosynthetic } \\ \text { dialysed }\end{array} & \begin{array}{c}\text { GS transferase } \\ \text { dialysed }\end{array} & \begin{array}{c}\text { GS biosynthetic } \\ \text { SVD treated }\end{array} & \begin{array}{c}\text { Alanine } \\ \text { dehydrogenase }\end{array} \\ 0 & 215 & 200 & 1085 & 210 & 0 \\ 5 & 0 & 215 & 1098 & 220 & 1 \\ 60 & 0 & 36 & 1090 & 220 & 1 \\ 180 & 0 & 22 & 895 & 180 & 2 \\ 300 & 0 & 39 & 756 & 157 & 21\end{array}$

\section{Table 2. Activities of various enzymes of nitrogen metabolism in T. neapolitanus grown under different limitations in the chemostat}

The dilution rate was $0.07 \mathrm{~h}^{-1}$ and the dissolved oxygen tension $50 \%$ of air saturation. The ability to reduce $\mathrm{NO}_{3}^{--}$was assayed with whole cells; dialysed cell-free extracts were used for the other assays.

\begin{tabular}{|c|c|c|c|c|c|c|c|c|}
\hline \multirow[b]{2}{*}{ Limitation } & \multicolumn{7}{|c|}{ Activity $\mid$ nmol $\min ^{-1}$ (mg protein $)^{-1} \mid$} & \multirow[b]{2}{*}{$\begin{array}{c}\text { Capacity } \\
\text { to reduce } \\
\mathrm{NO}_{3}^{-}\end{array}$} \\
\hline & $\begin{array}{c}\mathrm{N} \\
\text { source }\end{array}$ & $\begin{array}{l}\text { GS } \\
\text { biosyn- } \\
\text { thetic }\end{array}$ & $\begin{array}{c}\text { GS } \\
\text { trans- } \\
\text { ferase }\end{array}$ & $\begin{array}{c}\text { Glutamate } \\
\text { synthase }\end{array}$ & $\begin{array}{c}\text { Alanine } \\
\text { dehydro- } \\
\text { genase }\end{array}$ & $\begin{array}{c}\text { Glutamate } \\
\text { dehydro- } \\
\text { genase }\end{array}$ & $\begin{array}{c}\text { Alanine } \\
\text { amino- } \\
\text { trans- } \\
\text { ferase }\end{array}$ & \\
\hline Thiosulphate & $\mathrm{NH}_{4}^{+}$ & ND & 100 & 127 & 21 & 2 & 14 & - \\
\hline Thiosulphate & $\mathrm{NO}_{3}^{-}$ & 250 & 1033 & 194 & ND & ND & NM & + \\
\hline Thiosulphate & Urea & 252 & 1060 & 152 & ND & ND & NM & NM \\
\hline Nitrogen & $\mathrm{NH}_{4}^{+}$ & 215 & 1085 & 130 & ND & ND & 14 & + \\
\hline Nitrogen & $\mathrm{NO}_{3}^{-}$ & 246 & NM & 238 & ND & ND & NM & + \\
\hline Nitrogen & Urea & 370 & 2040 & 191 & ND & ND & NM & + \\
\hline $\mathrm{CO}_{2}$ & $\mathrm{NH}_{4}^{+}$ & 50 & 210 & 161 & ND & 2 & 15 & - \\
\hline $\mathrm{CO}_{2}$ & $\mathrm{NO}_{3}^{-}$ & 446 & 2700 & 154 & ND & ND & NM & + \\
\hline
\end{tabular}

ND, Not detectable; NM, Not measured.



Fig. 1. The biosynthetic activity of glutamine synthetase (GS) (i.e. the ATP-dependent production of glutamine from glutamate and ammonia) (O), the transferase activity of GS (i.e. the production of $\gamma$-glutamylhydroxymate from glutamine and hydroxylamine) (O), and the activity of glutamate synthase (GOGAT) $(\triangle)$, in dialysed cell-free extracts of $\mathrm{NH}_{4}^{+}$-limited $T$. neapolitanus cells as a function of dilution rate. The dissolved oxygen tension was $50 \%$ of air saturation. 
in the pH optima of the GS biosynthetic and GS transferase activities as a consequence of adenylylation, in contrast to the findings of Janssen et al. (1980) for Pseudomonas aeroginosa. The GS biosynthetic activity was a nearly constant proportion (16 to $25 \%$ ) of the GS transferase activity (Table 2), so during steady-state conditions either a constant or a relatively very small proportion of the total GS would be adenylylated. A pronounced shift in the extent of adenylylation of GS was, however, detected after the $\mathrm{NH}_{4}^{+}$shock (Table 1), until all GS was adenylylated. Treatment of whole cells with the stabilizing agent cetyltrimethylammonium bromide (Bender et al., 1977) had no effect on GS biosynthetic activity (not shown). During thiosulphate-limited growth $\left(7.7 \mathrm{mM}^{-} \mathrm{NH}_{4}^{+}\right)$, GS was fully adenylylated, since no GS biosynthetic activity was detected, whereas GS transferase activity was measurable (Table 2 ). SVD treatment of the cell-free extract resulted in a GS biosynthetic activity of $19 \mathrm{nmol} \mathrm{min}-1$ (mg protein) $)^{-1}$ (Table 1), which again was about $20 \%$ of the GS transferase activity.

Regulation of the rate of synthesis of GS. $\mathrm{Mn}^{2+}$-dependent GS transferase activity was detected in cell-free extracts of $T$. neapolitanus during all growth conditions (Table 2). As GS transferase activity is not subject to modification, activities of dialysed extracts provide an estimate of the quantity of GS protein. It is obvious from Table 2 that the GS transferase activity was dependent on the growth-limiting substrate, on the applied nitrogen source and also (Fig. 1) on the growth rate. In N-limited cultures, the GS transferase activity was derepressed about 10 - to 20 -fold compared with thiosulphate-limited cultures with excess $\mathrm{NH}_{4}^{+}(7.7 \mathrm{~mm})$. The derepression of the GS transferase is a result of the low intracellular $\mathrm{NH}_{4}^{+}$concentration rather than the physiological state of the cell (i.e. thiosulphate limitation or $\mathrm{N}$ limitation), since the GS transferase activity was also derepressed during thiosulphate limitation with excess $\mathrm{NO}_{3}^{-}$or urea. During $\mathrm{NH}_{4}^{+}$-limited growth, the GS transferase and the GS biosynthetic activity both increased with decreasing dilution rate (= growth rate) (Fig. 1). This is probably due to the decreasing concentration of the growth-limiting substrate $\left(\mathrm{NH}_{4}^{+}\right)$ with decreasing dilution rate.

\section{Assimilation pathways of ammonia under various growth conditions}

The derepression of GS during $\mathrm{N}$-limited growth indicates that nitrogen is assimilated via GS to glutamine under these conditions. Glutamine can be metabolized to glutamate in an NADPH- and 2-oxoglutarate-dependent reaction catalysed by glutamate synthase (GOGAT). GOGAT activity varied only twofold, with maximal activity during $\mathrm{NO}_{3}^{-}$-limited growth and minimal activity during thiosulphate-limited growth with $\mathrm{NH}_{4}^{+}$as nitrogen source (Table 2). GOGAT activity appeared to be independent of the growth rate during $\mathrm{NH}_{4}^{+}$-limited growth. During thiosulphate (energy)-limited growth with excess $\mathrm{NH}_{4}^{+}$as nitrogen source, no GS biosynthetic activity was detected because GS was completely adenylylated (see above). Under these conditions $\mathrm{NH}_{4}$ assimilation is probably catalysed by alanine dehydrogenase (ADH), since this enzyme was sufficiently active to support the growth rate. Given a nitrogen content of $10 \%$ of the dry weight (unpublished results) it can be calculated that the required specific rate of nitrogen assimilation at a growth rate of $0.07 \mathrm{~h}^{-1}$

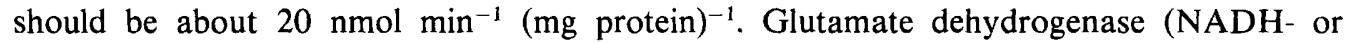
NADPH-dependent) was insufficiently active to explain the growth rate during thiosulphate limitation and during $\mathrm{CO}_{2}$ limitation with excess $\mathrm{NH}_{4}^{+}$(Table 2). The alanine formed by action of $\mathrm{ADH}$ might serve as an $\mathrm{NH}_{4}^{+}$donor in transaminase reactions. Activity of one enzyme catalysing such a reaction, L-alanine : 2-oxoglutarate aminotransferase, was constant during all growth conditions tested (Table 2). ADH activity was induced slowly after the addition of excess $\mathrm{NH}_{4}^{+}$to an $\mathrm{NH}_{4}^{+}$-limited culture (Table 1). Considering the low ADH activity shortly after the change-over, $\mathrm{NH}_{4}^{+}$assimilation would only partly be catalysed by ADH. Since the biosynthetic activity of GS was readily detected after dialysis (albeit decreased, due to partial adenylylation) $\mathrm{NH}_{4}^{+}$must be expected to be assimilated mainly via this enzyme until ADH is fully induced. Deadenylylated GS biosynthetic activity disappeared during this change-over at a rate equal to the dilution rate (Table 1). 
Table 3. Concentrations of the excretion products of $\mathrm{T}$. neapolitanus during $\mathrm{NH}_{4}^{+}$-limited growth in the chemostat

The dissolved oxygen tension during growth was $50 \%$ of air saturation. The concentrations are expressed as $\mathrm{mg} \mathrm{Cl}^{-1}$.

\begin{tabular}{|c|c|c|c|c|c|c|}
\hline $\begin{array}{c}\text { Dilution } \\
\text { rate } \\
\left(\begin{array}{ll}h & 1\end{array}\right)\end{array}$ & $\begin{array}{l}\text { Total C } \\
\text { excreted }\end{array}$ & Succinate & 2-Oxoglutarate & Pyruvate & Ethylmalonate & $\begin{array}{l}p \text {-Hydroxyphenyl- } \\
\text { acetate }\end{array}$ \\
\hline 0.03 & 23 & 8 & 9 & 5 & 1 & 0 \\
\hline 0.05 & 19 & 5 & 5 & 4 & 4 & 1 \\
\hline 0.07 & 16 & 3 & 3 & 1 & 4 & 5 \\
\hline
\end{tabular}

During $\mathrm{CO}_{2}$-limited growth with excess $\mathrm{NH}_{4}^{+}$, GS appeared not to by adenylylated and the activity had increased about twofold relative to a thiosulphate-limited culture with excess $\mathrm{NH}_{4}^{+}$(table 2). These results suggest that during $\mathrm{CO}_{2}$ limitation, when excess energy is available, $\mathrm{NH}_{4}^{+}$is also assimilated through GS in T. neapolitanus.

\section{$\mathrm{NO}_{3}^{-}$assimilation in $\mathrm{T}$. neapolitanus}

$\mathrm{NO}_{3}^{-}$assimilation proceeds through $\mathrm{NO}_{2}^{-}$and $\mathrm{NH}_{4}^{+}$in bacteria in reactions catalysed by nitrate reductase and nitrite reductase, respectively (Dalton, 1979). Eight molecules of $\mathrm{NAD}(\mathrm{P}) \mathrm{H}$ have to be oxidized to reduce each $\mathrm{NO}_{3}^{-}$to $\mathrm{NH}_{4}^{+}$. In spite of numerous attempts, nitrate reductase activity was not detectable in cell-free extracts of $T$. neapolitanus grown on $\mathrm{NO}_{3}^{-}$as a nitrogen source. An in vivo assay based on the detection of the $\mathrm{NO}_{2}^{-}$formed was therefore used. Since part of the $\mathrm{NO}_{2}^{-}$formed would be further reduced to $\mathrm{NH}_{4}^{+}$, it appeared impossible to quantify the $\mathrm{NO}_{3}^{-}$-reducing activity. It was clear, however, that bacteria grown under $\mathrm{N}$ limitation $\left(\mathrm{NH}_{4}^{+}, \mathrm{NO}_{3}^{-}\right.$or urea) were able to reduce $\mathrm{NO}_{3}^{-}$, whereas those grown under thiosulphate limitation or $\mathrm{CO}_{2}$ limitation with excess $\mathrm{NH}_{4}^{+}$were unable to reduce $\mathrm{NO}_{3}^{-}$ (Table 2). As expected, bacteria grown under thiosulphate or $\mathrm{CO}_{2}$ limitation with excess $\mathrm{NO}_{3}^{-}$ were also able to reduce $\mathrm{NO}_{3}^{-}$(Table 2). From these observations it was concluded that $\mathrm{NO}_{3}^{-}$-reducing capacity was derepressed during $\mathrm{N}$-limited growth and repressed during thiosulphate or $\mathrm{CO}_{2}$ limitation when no $\mathrm{NO}_{3}^{-}$was available to the cells. $\mathrm{NO}_{3}^{-}$per se is not necessary to derepress $\mathrm{NO}_{3}^{-}$reductase.

\section{Mutualistic interactions between T. neapolitanus and $N_{2}$-fixing heterotrophs}

During $\mathrm{NH}_{4}^{+}$-limited growth at dilution rates of $0.03,0.05$ and $0.07 \mathrm{~h}^{-1}$, about $24 \%$ of total fixed carbon was excreted into the medium by $T$. neapolitanus. The excretion products were identified, by gas-liquid chromatography, to be 2-oxoglutarate, succinate, pyruvate, ethylmalonate and $p$-hydroxyphenylacetate. The concentrations of the individual excretion products were dependent on the growth rate (Table 3 ).

Microbial mutualism was reported to occur between Thiobacillus ferrooxidans and the $\mathrm{N}_{2}$-fixing Beijerinckia lacticogenes (Tsuchiya et al., 1974). It was suggested that $B$. lacticogenes would grow on the excretion products of the autotrophic $T$. ferrooxidans and that $T$. ferrooxidans would benefit from $\mathrm{NH}_{4}^{+}$excreted by $B$. lacticogenes. It was postulated that an analogous situation might occur if $T$. neapolitanus were to be grown in mixed cultures with $\mathrm{N}_{2}$-fixing heterotrophs. Several $\mathrm{N}_{2}$-fixing bacteria were tested for growth on supernatant fluid of $\mathrm{NH}_{4}^{+}$-limited cultures of $T$. neapolitanus. Xanthobacter flavum was able to grow, while fixing $\mathrm{N}_{2}$, on the $T$. neapolitanus supernatant, whereas Beijerinckia indica, Azotobacter vinelandii and Klebsiella pneumoniae did not grow. A mixed culture of $T$. neapolitanus and $X$. flavum $\left(D, 0.05 \mathrm{~h}^{-1}\right.$; dissolved $\mathrm{pO}_{2}, 5 \%$ of air saturation) during $\mathrm{NH}_{4}^{+}$ limitation with excess thiosulphate did not show significantly higher yields as compared with a pure culture of $T$. neapolitanus under the same growth conditions. The low oxygen tensions which were applied to minimize inhibition of nitrogenase by $\mathrm{O}_{2}$ did not significantly influence the pattern of excretion products of T. neapolitanus in pure culture (not shown). 
DIS CUSSION

The obligate chemolithotroph $T$. neapolitanus appears to be very flexible with respect to the assimilation of nitrogen compounds. Glutamine synthetase plays a key role in nitrogen assimilation during $\mathrm{N}$ - and $\mathrm{CO}_{2}$-limited growth, and also during energy-limited growth when $\mathrm{NO}_{3}^{-}$or urea are applied as a nitrogen source. During energy-limited growth $\left(7.7 \mathrm{mM} \mathrm{NH} \mathrm{NH}_{4}^{+}\right.$, $\mathrm{NH}_{4}^{+}$assimilation is probably catalysed by alanine dehydrogenase, which was induced under these conditions (Table 2). Furthermore, alanine was the principally labelled amino acid during short-term $\left[1-{ }^{14} \mathrm{C}\right.$ lglycollate labelling studies carried out with thiosulphate-limited $T$. neapolitanus cells, but was not one of the early labelled products in $\mathrm{NH}_{4}^{+}$-limited cells (Beudeker et al., 1981).

Less energy is consumed when $\mathrm{NH}_{4}^{+}$assimilation is catalysed by alanine dehydrogenase than by the GS/GOGAT pathway. In a mutant of Methylophilus methylotrophus which possesses GDH instead of the wild-type GS/GOGAT, methanol yields are roughly 4 to $7 \%$ higher than in the wild type (Windass et al., 1980). It should therefore be expected that the operation of the GS/GOGAT pathway in urea-grown $T$. neapolitanus cells should lead to lower yields during energy limitation. In fact the yields were more than $10 \%$ lower. As expected, yields of $\mathrm{NO}_{3}^{-}$-grown cells were even lower, because the reduction of nitrate requires reducing power in the form of $\mathrm{NAD}(\mathrm{P}) \mathrm{H}$. In $T$. neapolitanus, reduced pyridine nucleotides must be formed directly through the oxidative pentose phosphate cycle or indirectly through the energy-consuming reversed electron transport. Alanine dehydrogenase has also been found to play a role in the assimilation of nitrogen in the cyanobacterium Anabaena cylindrica grown at high $\mathrm{NH}_{4}^{+}$concentrations (Rowell \& Stewart, 1976).

The obligate chemolithotrophic thiobacilli show many physiological similarities with the obligate phototrophic cyanobacteria (for reviews see Smith \& Hoare, 1977; Matin, 1978). GS in $T$. neapolitanus appears to be regulated not only by repression/derepression of enzyme synthesis and inhibition by low molecular weight compounds, but also by adenylylation control. No adenylylation system controlling GS activity has hitherto been reported for cyanobacteria (Rowell et al., 1979; Stacey et al., 1979). In Escherichia coli, and also in Klebsiella aerogenes, the average state of adenylylation of GS is determined by the ratio of 2-oxoglutarate to glutamine inside the cell (see review by Dalton, 1979). The excretion of 2-oxoglutarate by $T$. neapolitanus during $\mathrm{N}$-limited growth (Table 3 ) is probably due to a high intracellular concentration of this compound. Thus the deadenylylation of GS during $\mathrm{N}$-limited growth of $T$. neapolitanus might also be a consequence of the 2-oxoglutarate/ glutamine ratio. Excretion of 2-oxoglutarate by obligate chemolithotrophic bacteria has also been reported by Pan \& Umbreit (1972). These authors detected pyruvate, 2-oxoglutarate and $p$-hydroxyphenylpyruvate as excretion products during autotrophic growth in batch culture. It was suggested that these compounds might prevent heterotrophic growth on glucose of the obligate chemolithotrophic bacteria, since growth occurred in dialysis culture on glucose/salts media, in the absence of their specific inorganic energy source. Though heterotrophic growth of these obligate chemolithotrophic bacteria could not be shown by others (Matin, 1978) the physiological background for the excretion of the reported products remained an unsolved problem. A physiological explanation for the excretion of the keto acids 2-oxoglutarate and pyruvate by $T$. neapolitanus can now be given, since these compounds serve as acceptor molecules for $\mathrm{NH}_{4}^{+}$in transaminase reactions, and thus will accumulate during N limitation. Perhaps the batch cultures of Pan \& Umbreit (1972) were $\mathrm{N}$-limited. Metabolism of succinate (another excretion product of $T$. neapolitanus during $\mathrm{N}$-limited growth: see Table 3) also depends on the presence of amino acids, since succinyl-CoA (directly derived from succinate) combines with glycine, in a reaction catalysed by 5 -aminolaevulinate synthase, to form 2 -amino-3-oxoadipate. It is suggested that lack of glycine results in intracellular accumulation of succinate and subsequently excretion. (Note that succinate is an end product of the tricarboxylic acid cycle in $T$. neapolitanus, since 2-oxoglutarate dehydrogenase is missing in this organism (see review by Matin, 1978)|. Pan 
\& Umbreit (1972), using thin-layer chromatography, detected $p$-hydroxyphenylpyruvate as an excretion product of $T$. neapolitanus, whereas we found $p$-hydroxyphenylacetate (identified by gas-liquid chromatography) as an excretion product of this bacterium. Intracellular accumulation of $p$-hydroxyphenylpyruvate (a precursor of tyrosine) due to a shortage of glutamate needed in the transaminase reaction, and subsequent decarboxylation to $p$-hydroxyphenylacetate may explain excretion of this compound by $T$. neapolitanus. At present no physiological explanation can be given for the excretion of ethylmalonate by $T$. neapolitanus.

The excretion of organic compounds by $T$. neapolitanus has ecological consequences. Heterotrophic bacteria will be able to grow in originally inorganic environments. Microbial mutualism between $\mathrm{N}_{2}$-fixing bacteria and $T$. neapolitanus, as has been suggested to occur between T. ferrooxidans and Beijerinckia indica (Tsuchiya et al., 1974) was not detected, however. This is possibly because T. ferrooxidans is itself able to fix $\mathrm{N}_{2}$ (Mackintosh, 1978), whilst $T$. neapolitanus is not.

These investigations were supported by the Foundation for Fundamental Biological Research (BION) which is subsidized by the Netherlands Organization for the Advancement of Pure Research (ZWO). We thank Mr Schierbeek (Department of Pediatrics, University of Groningen) for the analyses of the excretion products.

\section{REFERENCES}

Bender, R. A., Janssen, K. A., Rennick, A. O., Blumenberg, M., FoOR, I. \& MAgasanik, B. (1977). Biochemical parameters of glutamine synthetase from Klebsiella aerogenes. Journal of Bacteriology 129, 1001-1009.

Beudeker, R. F., Cannon, G. C., Kuenen, J. G. \& Shively, J. M. (1980). Relations between Dribulose-1,5-bisphosphate carboxylase, carboxysomes and $\mathrm{CO}_{2}$-fixing capacity in the obligate chemolithotroph Thiobacillus neapolitanus, grown under different limitations in the chemostat. Archives of Microbiology 124, 185-191.

Beudeker, R. F., Kuenen, J. G. \& CODd, G. A. (1981). Glycollate metabolism in the obligate chemolithotroph Thiobacillus neapolitanus grown in continuous culture. Journal of General Microbiology 126, 337-346.

Biggins, D. R. \& Postgate, J. R. (1969). Nitrogen fixation by cultures and cell free extracts of Mycobacterium flavum 301. Journal of General Microbiology 56, 181-193.

DALTON, H. (1979). Utilization of inorganic nitrogen by microbial cells. In Microbial Biochemistry. International Review of Biochemistry, vol. 21, pp. 227-266. Edited by J. R. Quayle. Baltimore: University Park Press.

Duran, M. (1974). A contribution to the study of organic aciduria. Doctoral thesis, University of Utrecht, The Netherlands.

Herbert, R. A., Siefert, E. \& Pfennig, N. (1978). Nitrogen assimilation in Rhodopseudomonas acidophila. Archives of Microbiology 119, 1-5.

JANSSEN, D. B., OP DEN CAMP, H. J. M., LEENEN, P. J. M. \& VAN DER DRIFT, C. (1980). The enzymes of the ammonia assimilation in Pseudomonas aeruginosa. Archives of Microbiology 124, 197-203.

JAWORSKI, E. G. (1971). Nitrate reductase assay in intact plant tissues. Biochemical and Biophysical Research Communications 43, 1274-1279.
Johansson, B. C. \& Gest, H. (1977). Adenylylation/ deadenylylation control of the glutamine synthetase of Rhodopseudomonas capsulata. European Journal of Biochemistry 81, 365-371.

KleinschmidT, J. A. \& Kleiner, D. (1978). The glutamine synthetase from Azotobacter vinelandii: purification, characterization, regulation and localization. European Journal of Biochemistry 89. 51-60.

Kuenen, J. G. \& VeldKamp, H. (1973). Effects of organic compounds on growth of chemostat cultures of Thiomicrospira pelophila, Thiobacillus thioparus and Thiobacillus neapolitanus. Archiv für Mikrobiologie 94, 173-190.

LEA, P. J. \& Miflin, B. J. (1975). Glutamate synthase in blue-green algae. Biochemical Society Transactions 3, 381-383.

LudwIG, R. A. (1978). Control of ammonium assimilation in Rhizobium $32 \mathrm{Hl}$. Journal of Bacteriology 135, 114-123.

Mackintosh, M. E. (1978). Nitrogen fixation by Thiobacillus ferrooxidans. Journal of General Microbiology 105, 215-218.

Matin, A. (1978). Organic nutrition of chemolithotrophic bacteria. Annual Review of Microbiology 32. 433-468.

MeiBERG, J. B. M. (1979). Metabolism of methylated amines in Hyphomicrobium spp. Doctoral Thesis, University of Groningen, The Netherlands.

PAN, P. \& Umbreit, W. W. (1972). Growth of obligate autotrophic bacteria on glucose in a continuous flow-through apparatus. Journal of Bacteriology 109, 1149-1155.

Rowell, P. \& Stewart, W. D. P. (1976). Alanine dehydrogenase of the $\mathrm{N}_{2}$-fixing blue-green alga, Anabaena cylindrica. Archives of Microbiology 107, $115-124$.

Rowell, P., Sampaio, M. J. A. M., Ladha, J. K. \& StEWART, W. D. P. (1979). Alteration of cyano- 
bacterial glutamine synthetase activity in vivo in response to light and $\mathrm{NH}_{4}^{+}$. Archives of Microbiology 120, 195-200.

SCHmidT, E. (1974). Glutamate dehydrogenase. UV assay. In Methods of Enzymatic Analysis, vol. 2, 2nd edn, pp. 650-656. Edited by H. U. Bergmeyer. New York: Academic Press.

Shapiro, B. M. \& StadtMan, E. R. (1970). Glutamine synthetase (Escherichia coli). Methods in Enzymology 17A, 910-922.

Smith, A. J. \& HoARE, D. S. (1977). Specialist photographs, lithotrophs and methylotrophs: a unity among a diversity of prokaryotes? Bacteriological Reviews 41, 419-448.

Stacey, G., van BaAlen, C. \& Tabita, F. R. (1979). Nitrogen and ammonia assimilation in the cyanobacteria: regulation of glutamine synthetase. Archives of Biochemistry and Biophysics 194, 457-467.
Strandburg, G. W. \& Wilson, P. W. (1968). Formation of the nitrogen fixing enzyme system in Azotobacter vinelandii. Canadian Journal of Microbiology 14, 25-31.

TYLER, B. (1978). Regulation of the assimilation of nitrogen compounds. Annual Review of Biochemistry 47, 1127-1162.

Tsuchiya, H. M., Trivedi, N. C. \& Schuler, M. L. (1974). Microbial mutualism in ore leaching. Biotechnology and Bioengineering 16, 991-995.

Vishniac, W. \& SANTER, M. (1957). The thiobacilli. Bacteriological Reviews 21, 195-213.

Windass, J. D., Worsey, M. J., Pioli, E. M., Pioli, D., Barth, T. D., Atherton, K. I., Dart, E. C., Byrom, D., Powell, K. \& Senior, P. J. (1980). Improved conversion of methanol to single-cell protein by Methylophilus methylotrophus. Nature, London 287, 396-401. 